dence of his intent may be mentioned his ignoring completely the existence of the American Confederation, which is in complete and effective possession of the field which he proposed to operate and improve. If Dr. Webster were simply desirous of assisting the medical boards and had proposed a plan of education only, he should not have ignored the two most important factors-medical boards, represented by the American Confederation, and the medical colleges, represented in a large degree by the Association of American Medical Colleges. I am pleased, however, to accept without further reservation, his statement that the Council on Medical Education proposes to limit its endeavors to the educational phase of the question.

In reference to that portion of Dr. Webster's reply which deals principally with himself and his personal achievements and services to the profession and to the causes of educational reciprocity, I have to say that I fully appreciate and gladly credit Dr. Webster's great ability as well as his activity in all matters pertaining to the good of the profession, and the objects it has in view, but I am not prepared to go the length of supporting him in his contention that either he or the National Confederation are the authors of the present method of standard adopted by the Association of American Medical Colleges, or by the American Confederation. He states that in 1903, and again in 1904, the National Confederation of State Medical and Licensing Boards adopted his standard curriculum, and that this curriculum, which assigned a certain number of hours in the course to each subject, was the first curriculum to be adopted by any organization, and that it was subsequently adopted by the Association of American Medical Colleges and the American Confederation without any important moditications. Is his statement based on facts? As early as July, 1900, the Michigan State Medical Board published and enforced an itemized medical standard, divided into lectures, teaching, and laboratory work, and in June, 1902, published a further itemized standard of both preliminary and medical education, the Iatter divided into lectures, Iaboratory, and clinics, while Dr. Webster's standard of three years later contains simply the total number of hours for each subject, without division into lectures, laboratory, and clinies, and therefore was a much less developed method, and possessed nothing of the Michigan original, except in its crudeness.

In 1904 the American Confederation adopted the Michigan method of standard, both of preliminary and medical education, but postponed the final adoption of the detail until subsequent to the 1905 meeting of the Association of American Medical Colleges, in order that the standards of the Confed. eration of Boards and the Association of Colleges should harmonize.

As a member of, and secretary of the confederation committee in charge of the standards, I can state that Dr. Webster's curriculum was not considered by the committee, or even aknown to have an existence. The committee of the Association of American Medical Colleges, of which Dr. Kober was chairman, in its printed report, which was adopted, presented in parallel columns the proposed standard of 4,000 hours, divided into lectures, laboratory, and clinies (exactly in harmony with the Michigan method) and the Michigan standard of 4,000 hours. With some slight variation in the detail of hours per subject these standards were exactly uniform.

Looking up the last two or three years' official report of the Association of Medical Colleges I find frequent reference to the Michigan standard and method, but no reference to Dr. Webster's curriculum, or the National Confederation. If those interested could see in print, for comparison, the curriculum of the National Confederation of 1903 and 1904, which Dr. Webster claims as his offspring, and the standard curriculum of the Association of American Medical Colleges, and also the Michigan curricula of each year since 1900, which have been incorporated in her application forms since 1902, the fallacy of Dr. Webster's claim of originality would be fully appreciated. Especially so in connection with his statement made at the Portland session last years, as follows:

"Dr. G. W. Webster of Illinois said that while

there had been much talk of raising the standard no

real standard has as yet been established."

As an additional evidence of inconsistency in Dr. Webster's claim might be mentioned the fact that the state board of which he is president, and its most influential member, has as yet failed to adopt the method of standard which he states was originated by him in 1903, and which was actually in practical use in Michigan three years prior to this date.

In connection with the above I also desire to refer briefly to the published letter of commendation received by Dr. Webster from Dr. George M. Kober, in which it would appear that the latter indorses his claim that he alone of all others deserves credit for the standard curriculum, which at a later date J). Webster denies exists.

I am pleased to note that Dr. Webster, like the rest of us, is subject to the human weakness of appreciating credit for personal good works. I also received an almost similar letter from Dr. Kober, with this difference, perhaps-the one letter was based on the belief and kindly appreciation for services attempted; the other on fact. While such letters are usual, proper, and often helpful, it was never contemplated by their author that they should be used in the manner Dr. Webster used the one received by him. They should never be taken too seriously or literally by the fortunate recipients, besides, such letters are not material to the cause which Dr. Webster and myself have at heart, and the methods of obtaining which we are now agreed on. Indeed, the discussion seems to have been diverted from the original subject of reciprocity to one of personal claims and credit, for which I do not hold myself responsible.

B. D. Harison.

\section{Lisbon and Its People.-Some Interesting Facts for Those Attending the International Congress.}

\section{BAITIMORE, March 1, 1906}

To the Editor:-Having received numerous letters of inquiry regarding Lisbon and its people $I$ take this opportunity to give a few facts to those who are to attend the congress. Being well acquainted with the people of Portugal, I regret that I can not do them greater justice, but material for a medical journal has its limits.

Contrary to the general opinion, Portugal differs sensibly from Spain in its social, intellectual and moral life. Ethnographically the inhabitants of the two countries are the same race, but apart from this there is a great difference between the two races.

The primitive traits of the Portuguese have been changed by long series of mixtures between the original inhabitants and foreigners. This amalgam, which was produced during and directly after Portugal's great geographical discoveries, has brought about a physiognomic difference which is noticeable the moment the traveler reaches the Spanish-Portuguese frontier.

Throughout Portugal the national type remains the same, but the mode of life, costumes, habits and morals vary in different parts of the country. These differences are distinct; for instance, the Minhotos are cultivators of the son, intelligent and serious in their work, but on fete days they are gay, joyous and great admirers of pretty women and jewelry. The grape pickers and winegrowers of Douro, the inhabitants of the Beira, sometimes shepherds, ometimes fisherwen, are hard workers, but their tasks finished thcy enjoy themselves in sports and drinking. The mountaineers are a strong, virile race with meditative manners and austere morals.

One feature, however, is characteristic of all Portugal. This is the beautiful, brille nt and desirous eyes of the women. The latter are handsome, have blooming complexions and in all anatomic traits accentuate their sex. Short in stature, they are well proportioned, esthetic in carriage, opulent in physiologic functions, and have pretty, tiny feet and hands. Their shining and jetty hair makes a striking contrast to their milkwhite foreheads, rosy cheeks and pink lips.

Intellectually and morally the Portuguese offer an interesting melange of good qualities and bad faults. They are a lovable race when you know them well. They are invariably kind to the poor, gentle to their beasts, and open-hearted to the properly introduced foreigner.

It is announced that the members of the congress will be invited to witness a bullfight in Lisbon. I advise everyone to go. You may with perfect security to ang sensitiveness take your wives and daughters. A Portuguese bullfight differs 
from a Spanish bullfight as much as a game of bean-bag differs from a college football game. There is no bloodshed, nothing repugnant, but plenty of hilarity, and frequently great athletic ability is displayed by men, horses and bulls. On the short horns of the latter are placed large rubber balls. Sometimes the horse manages to kick the bull in the ribs, when he utters a roar of indignation and returns the insult by butting the horse with his rubber buffers. This pleases the risible centers of the happy Portuguese and the bullfight is over.

There is much that pertains to the Orient in the customs and architecture of Portugal, and the many social laws are; undoubtedly only modified conditions that existed when the Moors ruled the peninsula.

The higher classes in Lisbon and Oporto well appreciate the value of educating their daughters, yet conditions are such that the girls must be confined to conventual supervision. In order to maintain this oversight on the young women, yet have them free to enjoy the learning of other countries, they are taught by English and Irish women. The great convent schools of Bom Successo and Salesias, where the girls of the best society are sent, are controlled exclusively by English and Irish sisters.

This naturally brings me to what I shall have to confine myself in this article-educational matters-though I feel no adequate justice can be done to the charming Portuguese people by neglecting to tell of their home life, or of the struggle educated people, including the king, are making for freedom in religious thought.

There exists in Portugal only one educational institution bearing the honor and title of a university. This was founded in Lisbon in 1288 and transferred in 1307 to Coimbre (pro. nounce, but do not indite, Quimbre). A bull of Gregory XI was issued October, 1376, which authorized the university to give degrees in letters and theology. In 1377 the university was again transferred to Lisbon, but 200 years later removed to its former home, Coimbre, where it has remained. It has been the battleground for science and religion through many a century. In 1836 came the great movement of the reformers and then were established under the direct control of the government the departments of medicine, law and the arts Gradually it became a school of modern ideas, and has kept well up in the progress of nations.

The university is composed of five faculties: medicine, law, theology, mathematics and physics. This sast faculty has under its control all instruction in the natural sciences and attached to it are excellent botanical and zo logical gardens. The chairs of Greek and Hebrew are under the charge of the theological faculty. The university buildings are massive, handsome and unique in their architectural designs. They should be well studied, for nowhere throughout the world will the traveler find their equal. The library is large, its decorations are rich and immensely valuable, and combine all the Oriental splendor of the Alhambra with the utility of the libraries in St. Mark's, Venice.

The course of instruction at the great Portugal university is essentially modern in that it is free from church interference and generously supported by the state. The professors and those foreigners who are invited to talk to the students have the freedom of the air to say what they think. (This in some respects differs from a few of our universities.)

The professors of Coimbre, all Portuguese, are divided into fifty-three lecturers (lentes) and twenty-two associate lecturers (substitutos). The members of the different faculties are designated by their capes and hats, as follows: Medicine, yellow, 18 members; law, red, 21 members; mathematics, blue, 13 members; philosophy, blue and white, 11 members, and theology, white, 9. On all official occasions and at examinations the professors are dressed in their distinctive robes and hats. The students are obliged to wear a uniform of black cloth, composed of short breeches, cape and black nat, of a disgraceful shape and size. For this latter reason the students go bareheaded except on official occasions.

The last statistics show that there are 1,180 students in all departments, divided as follows: Law, 510; mathematics, 130 ; medicine (and pharmacy), 140; and in the natural sciences,
360 , while it will undoubtedly surprise many readers to learn that in the department of theology there are only 40 students.

The course is five years, and the charge for instruction about $\$ 30$ a year, except in medicine, where it is somewhat greater. The minimum age is 16 years, but the average age of the students is about 19 . Women are rarely seen at the university, the woman of eunuchal tendency not yet having arrived at Portugal. One lone woman of mixed inheritance received a degree of philosophy in 1894. She has disappeared. There are few foreigners at the university, unless we class the Brazilians as such. These latter of Portuguese blood, attend in large numbers.

In Oporto there is a school of medicine where instruction is of a high type. No degrees are conferred by this school, applicants having to pass the examination at Coimbre.

William Lee Howard, M.D.

\section{The Physician and the Pharmacopeia.}

New York, Feb. 18, 1906.

T'o the Editor:-I thank you for your courtesy in printing my letter with the above title in your pages (February $17, \mathrm{p}$. 526). Your answer, however, requires a reply on my part. You say: "We do not believe anyone suggests that we should be limited to Pharmacopeial preparations." And further you make the statement: "Our correspondent, like too many others, has set up a straw man to knock down." Now, I am not given to setting up straw men, and I am not very likely to make absurd statements, when the subject of proprietary remedies is under discussion, as $I$ have studied the question from all sides, in all its phases, and at a time when too many who show now such commendable zeal on the subject were an absolute terra incognita. I could name you a dozen good, but ignorant men, who just did show themselves so narrowminded and so bigoted as to condemn-condemn utterlyevery proprietary and non-Pharmacopeial preparation. But I can do better than that. In THE Journal of the American Medical Association, January 20 (p. 221, col. 1), Dr. Frank G. Wheatley makes the statement that "the time has come when there are no ethical preparations. We should ignore the whole list. If we will confine our prescribing to articles recognized by the national authority, [The Pharmacopeia], we shall confer one of the greatest boons on the public, and incidentally on ourselves, that the annals of medicine record." And on the same page, column 2, Dr. James C. White is reported as saying, that "though in practice fifty years he had never preseribed a single remedy outside of those contained in the Pharmacopeia." (I wonder if he used cocain between 1884 and 1894, as it was only in the latter year that cocain became official, while Koller discovered it in 1884.) So you see, there are men, so ill-informed, so narrow-minded, as to advocate the non-use of any non-Pharmacopeial preparations. And it was against them that my letter was directed. For I fear that through excess of zeal, through misdirected energy, through intemperate statements of ill-informed persons, who are not familiar with the actual needs of the every day practitioner, our entire work, our labor for years, may go for naught.

William J. Robinson, M.D.

\section{Poison Ivy.}

Washington, D. C., March 6, 1906

To the Editor:-In The JourNaL, Jan. 27, 1906, page 301, you quote from the Cincinnati Lancet-Clinic from an article by Dr. E. S. McKee on the subject of poisoning by poison oak or ivy. Is it possible that the work of Pfaff, published in the Journal of Experimental Medicine (1897, vol. ii, No. 2), is not yet known to the profession?

Dr. MeKee "has been poisoned twice by these plants and feels that he knows many times more about the trouble than he possibly could have known had he not had this experience." I have been poisoned about eignty times and feel that I also know something of the condition.

As a result of the work of Pfaff, we know that the irritant substance of Rhus toxicodendron and Rhus venenata is a fixed oil which is soluble in alcohol and which is precipitated by lead subacetate. The oil is similar to cardol, but is probably not 